WSRC-TR-97-00383, Rev. 0

Decomposition Studies of Filtered Slurries using the Enhanced Comprehensive Catalyst (U)

W. R. Wilmarth

C. L. Crawford

R. A. Peterson

Publication Date: November 13, 1997

Westinghouse Savannah River Company Savannah River Technology Center

Aiken, SC 29808

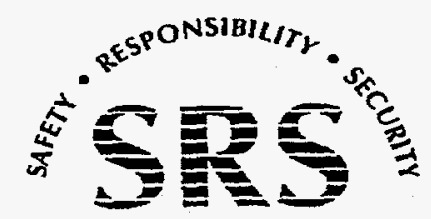




\section{DISCLAIMER}

This report was prepared as an account of work sponsored by an agency of the United States Government. Neither the United States Government nor any agency thereof, nor any of their employees, makes any warranty, express or implied, or assumes any legal liability or responsibility for the accuracy, completeness, or usefulness of any information, apparatus, product, or process disclosed, or represents that its use would not infringe privately owned rights. Reference herein to any specific commercial product, process, or service by trade name, trademark, manufacturer, or otherwise does not necessarily constitute or imply its endorsement, recommendation, or favoring by the United States Government or any agency thereof. The views and opinions of authors expressed herein do not necessarily state or reflect those of the United States Government or any agency thereof.

This report has been reproduced directly from the best available copy.

Available to DOE and DOE contractors from the Office of Scientific and Technical Information, P.O. Box 62, Oak Ridge, TN 37831; prices available from (615) 576-8401.

$$
423
$$

Available to the public from the National Technical Information Service, U.S. Department of Commerce; 5285 Port Royal Road, Springfield, VA 22161. 


\section{DISCLAIMER}

Portions of this document may be illegible electronic image products. Images are produced from the best available original document. 


\title{
Decomposition Studies of Filtered Slurries using the Enhanced Comprehensive Catalyst (U)
}

\author{
W. R. Wilmarth, C. L. Crawford and R. A. Peterson \\ Waste Processing Technology Section \\ Savannah River Technology Center \\ Westinghouse Savannah River Company
}

\begin{abstract}
This study examined decomposition of the soluble phenylborates at elevated temperature $\left(45^{\circ} \mathrm{C}\right)$ to determine the effects of filtering the solid tetraphenylborate, solid sludge and monosodium titanate and spiking additional levels of transition metal catalysts. Results from these tests are used to predict benzene generation rates for the aerated Tank $50 \mathrm{H}$. Analysis of the results of these tests provide the following conclusions.

- Tetraphenylborate reacts in air-sealed vessels after an extended time at $45^{\circ} \mathrm{C}$.

-Calculated rate constants resemble those for copper catalysis.

-Further addition of copper or palladium does not increase the observed rate of decomposition.
\end{abstract}

- Triphenylborane reacted at rates similar to copper catalyzed systems in any of the tested filtrate media.

- Rate constants for the lower phenylborate species (2PB and 1PB) have been measured and reaction rates are rapid with a half life at $45^{\circ} \mathrm{C}$ of $\sim 100 \mathrm{~h}$.

- Phenol is favored over benzene as a reaction product in the flowing air systems and would reduce the overall benzene generation if air sparging is an option.

\section{Introduction}

Over the past several months, the Waste Processing Technology Section has been investigating the decomposition of sodium tetraphenylborate and other phenylborate species in alkaline, aqueous systems in support of the resumed operations of the In-Tank Precipitation (ITP)

facility. ${ }^{1-3}$ The results of these studies has provided significant insight into the chemical processes in Tank $48 \mathrm{H}$ and Tank $49 \mathrm{H}$ which involve either the precipitation or storage of potassium and cesium tetraphenylborate solids. 
Decontaminated salt solution from this precipitation process transfers to Tank $50 \mathrm{H}$. This tank differs from either Tank $48 \mathrm{H}$ or $49 \mathrm{H}$ in that the operation uses an air-based system while Tanks $48 \mathrm{H}$ and $49 \mathrm{H}$ remain inerted. This air operation in Tank $50 \mathrm{H}$ drives control of the safety of deflagrations and explosions to control of the fuel. The potential fuel in Tank $50 \mathrm{H}$ is benzene generated by the decomposition of sodium tetraphenylborate and other phenylborate decomposition products. These phenylborate compounds exhibit high solubilities and react with several transition metals ${ }^{5-7}$ under these conditions. As a result, High-Level Waste Engineering requested the Savannah River Technology Center to investigate the nature of this decomposition reaction in the absence of solids to estimate the benzene generation rate for catalyst-containing filtrate solutions. The reactivity of the filtrate may prove quite lower than the slurry.

\section{Experimental}

Researchers initiated the decomposition of the phenylborates in simulated Batch 2 slurries containing the Enhanced Comprehensive Catalyst (ECC). A slurry of precipitated potassium tetraphenylborate was prepared by the addition of an excess of sodium tetraphenylborate. The soluble tetraphenylborate ion was observed to react prior to filtration. Subsequently, the decomposition of the soluble phenylborate species in the filtrate was monitored as a function of time.

Personnel dissolved reagent-grade chemicals in distilled, deionized water to provide $1 \mathrm{~L}$ of stock solution to simulate the ITP Batch 2 composition as shown in Table 1. Sodium tetraphenylborate was added to precipitate the potassium ion and to provide an excess $(\sim 800 \mathrm{mg} / \mathrm{L})$ of sodium tetraphenylborate. The slurry was stirred for three days to equilibrate. A qualitative test was performed to determine if soluble sodium tetraphenylborate existed in solution. This test consisted of adding a few drops of a potassium solution to an aliquot of filtered slurry. A positive test for soluble sodium tetraphenylborate resulted in the precipitation of potassium tetraphenylborate upon the addition of potassium ion.

Sodium tetraphenylborate was eventually added in the form of $0.55 \mathrm{M}$ solution, solid (Boulder Scientific), and as a powder (Aquafine) before the qualitative test was positive. The total amount of sodium tetraphenylborate added produced a $4 \mathrm{wt} \%$ sodium tetraphenylborate slurry.

The ECC, as described in Table 2, was added and researchers removed aliquots $(\sim 4 \mathrm{~mL})$ of the slurry or supernate and filtered using a 0.45 micron syringe filter to remove sodium/potassium tetraphenylborate solids. These filtered samples were submitted for analysis by High

Performance Liquid Chromatography (HPLC) using routine quality assurance protocols. ${ }^{10}$ This slurry preparation experiment continued for one week to allow the reaction to proceed. 
Table 1. Batch 2 Simulant

\begin{tabular}{llll}
\hline Chemical & Conc. (M) & Target(g) & Actual $(\mathrm{g})$ \\
$\mathrm{Al}\left(\mathrm{NO}_{3}\right)_{3}$ & 0.2 & 75.06 & 75.08 \\
$\mathrm{KNO}_{3}$ & 0.036 & 3.64 & 3.63 \\
$\mathrm{NaNO}_{2}$ & 0.7 & 48.3 & 48.33 \\
$\mathrm{Na}_{2} \mathrm{CO}_{3}$ & 0.28 & 34.7 & 34.73 \\
$\mathrm{NaOH}$ & 3.6 & 144.0 & 144.07 \\
\hline
\end{tabular}

Personnel removed the slurry from the oven and filtered using a medium frit glass filter without cooling the slurry. The filtrate was then divided into four fractions for further testing. Two of these tests used glass vials as the reaction vessel as previously described, ${ }^{11}$ and equipped to provide for flowing air. The other two reaction vessels were the standard $160-\mathrm{mL}$ serum vials. Approximately $100 \mathrm{~mL}$ of the filtrate was added to each vial and placed at $45^{\circ} \mathrm{C}$. During this experiment, researchers removed aliquots $(\sim 4 \mathrm{~mL})$ of the slurry or filtrate and filtered using a 0.45 micron syringe filter. These filtered samples were submitted for analysis by High Performance Liquid Chromatography (HPLC) using routine quality assurance protocols. ${ }^{10}$

Finally, researchers added soluble copper or palladium catalyst at $10 \mathrm{mg} / \mathrm{L}$ to each reaction vessel. Decomposition of the phenylborate species was followed for several weeks with the reaction vessels at $45^{\circ} \mathrm{C}$. In spiking the palladium-containing solutions, a different, incorrect stock solution was used and initial concentrations were only $1.3 \mathrm{mg} / \mathrm{L}$. Later additions raised the palladium concentration to $10 \mathrm{mg} / \mathrm{L}$. Personnel monitored the temperatures within the air space of the ovens to $\pm 3{ }^{\circ} \mathrm{C}$ using thermometers traceable to NIST standards. Researchers monitored the oven display and thermometer reading during the days and shift operating personnel monitored these readings during the night shifts.

Data gathered during these experiments are recorded in accordance with Procedure 4.10 of the L1 Manual, SRTC Procedures Manual. The laboratory notebook, WSRC-NB-97-61, will provide lifetime storage as a record. Furthermore, data collected and procedures used in this study were prepared in accordance with the Task Technical Plan ${ }^{11}$ and Task Quality Assurance Plan. ${ }^{12}$ 
Table 2. Enhanced Comprehensive Catalyst

Soluble Metal Additives:

$\mathrm{Cu} \quad 1.7 \mathrm{mg} / \mathrm{L}$

$\mathrm{Ru} \quad 0.8 \mathrm{mg} / \mathrm{L}$

$\mathrm{Rh} \quad 0.2 \mathrm{mg} / \mathrm{L}$

$\mathrm{Pd} \quad 0.4 \mathrm{mg} / \mathrm{L}$

$\mathrm{Ag} \quad 0.6 \mathrm{mg} / \mathrm{L}$

$\mathrm{Fe} \quad 2.6 \mathrm{mg} / \mathrm{L}$

$\mathrm{Cr} \quad 60 \mathrm{mg} / \mathrm{L}$

$\mathrm{Hg} \quad 2.2 \mathrm{mg} / \mathrm{L}$

$\mathrm{Cd} \quad 0.4 \mathrm{mg} / \mathrm{L}$

$\mathrm{Zn} \quad 8.7 \mathrm{mg} / \mathrm{L}$

Mo $12 \mathrm{mg} / \mathrm{L}$

$\mathrm{Ce} \quad 0.3 \mathrm{mg} / \mathrm{L}$

$\mathrm{Si} \quad 16 \mathrm{mg} / \mathrm{L}$

Se $1 \mathrm{mg} / \mathrm{L}$

As $\quad 0.04 \mathrm{mg} / \mathrm{L}$

$\mathrm{Pb} \quad 1.2 \mathrm{mg} / \mathrm{L}$

Sn $\quad 2.1 \mathrm{mg} / \mathrm{L}$

Co $\quad 0.04 \mathrm{mg} / \mathrm{L}$

$\mathrm{Ca} \quad 12.2 \mathrm{mg} / \mathrm{L}$

$\mathrm{Sr} \quad 0.1 \mathrm{mg} / \mathrm{L}$

La $\quad 0.05 \mathrm{mg} / \mathrm{L}$
Solid Additives:

MST $2 \mathrm{~g} / \mathrm{L}$

Sludge Solids $2 \mathrm{~g} / \mathrm{L}$ yielding:

$\mathrm{Cu}$

$2 \mathrm{mg} / \mathrm{L}$

$\mathrm{Ru} \quad 4.6 \mathrm{mg} / \mathrm{L}$

$\mathrm{Rh} \quad 1.2 \mathrm{mg} / \mathrm{L}$

$\mathrm{Pd} \quad 2.2 \mathrm{mg} / \mathrm{L}$

$\mathrm{Mn} \quad 118 \mathrm{mg} / \mathrm{L}$

$\mathrm{Fe} \quad 576 \mathrm{mg} / \mathrm{L}$

$\mathrm{Cr} \quad 4 \mathrm{mg} / \mathrm{L}$

$\mathrm{Ni} \quad 50 \mathrm{mg} / \mathrm{L}$

Al $\quad 96 \mathrm{mg} / \mathrm{L}$

$\mathrm{Mg} \quad 2 \mathrm{mg} / \mathrm{L}$

$\mathrm{Zn} \quad 4 \mathrm{mg} / \mathrm{L}$

$\mathrm{Pb} \quad 6 \mathrm{mg} / \mathrm{L}$

Organic Compounds:

Diphenylmercury $\quad 150 \mathrm{mg} / \mathrm{L}$

Benzene $\quad 750 \mathrm{mg} / \mathrm{L}$

\section{Experimental Results}

Where practical, the phenylborate species were analyzed as a function of time to derive pseudofirst order rate constants using Microsoft ${ }^{\oplus}$ Excel data regression function.

\section{Slurry Preparation}

To effectively simulate conditions in Tank $50 \mathrm{H}$, the Batch 2 simulated slurry was prepared and determined reactive prior to filtration. Table 3 shows the concentrations of the phenylborate species as a function of time. The soluble sodium tetraphenylborate concentration remained relatively unchanged with some dissolution of the solid tetraphenylborate. The soluble concentration remained nearly constant at $\sim 225 \mathrm{mg} / \mathrm{L}$. The slurry remained unreactive for 
approximately 100 hours at $45^{\circ} \mathrm{C}$. The triphenylborane concentration increased dramatically from non-detectable at the 42 hour sample to $1270 \mathrm{mg} / \mathrm{L}$ at the 135.5 hour sample. Similarly, the diphenylborinic acid and phenylboronic acid concentrations increased in the 135.5 hour sample.

Table 3. Phenylborate Concentration (mg/L) of Reactive Slurry

\begin{tabular}{cccccc}
\hline Elapsed Time (h) & $4 \mathrm{~PB}$ & $3 \mathrm{~PB}$ & $2 \mathrm{~PB}$ & $1 \mathrm{~PB}$ & Phenol \\
0 & 207 & 10 & 103 & 126 & 131 \\
21 & 223 & 10 & 84 & 124 & 154 \\
42 & 214 & 10 & 97 & 124 & 173 \\
135.5 & 256 & 1270 & 730 & 205 & 193 \\
161 & 271 & 1434 & 836 & 203 & 193 \\
\hline
\end{tabular}

Decomposition in Filtrate

Researchers followed the decomposition of the phenylborate species in filtrate from ECCcontaining slurries over a period of approximately 500 hours. In the four experiments, the initial soluble concentrations for sodium tetraphenylborate, triphenylborane, diphenylborinic acid, phenylboronic acid, and phenol ranged from 204 to $232 \mathrm{mg} / \mathrm{L}, 1312$ to $1332 \mathrm{mg} / \mathrm{L}, 802$ to 819 $\mathrm{mg} / \mathrm{L}, 199$ to $211 \mathrm{mg} / \mathrm{L}$, and 186 to $190 \mathrm{mg} / \mathrm{L}$, respectively. This uncertainty represents an estimate of the analytical and sampling error. Table 4 shows the observed concentrations of the phenylborate species as a function of time in these air sealed and air sparged filtrates. In addition, researchers analyzed the filtrate using Inductively Coupled Plasma - Emission Spectroscopy (ICP-ES) and ICP-Mass Spectrometry (ICP-MS) to determine the elemental composition of the filtrate. Table 5 contains these data. The potential catalysts identified by Barnes $^{13}$ are observed at slightly lower soluble concentrations than the total amounts added to the initial slurry. In particular, copper, rhodium and ruthenium are observed at $1-4 \mathrm{mg} / \mathrm{L}$; whereas, palladium is reduced to $0.05 \mathrm{mg} / \mathrm{L}$. 
Table 4. Phenylborate Concentrations ( $\mathrm{mg} / \mathrm{L}$ ) in Air Sealed and Air Sparged Filtrates

\begin{tabular}{|c|c|c|c|c|c|}
\hline Elapsed Time (h) & $4 \mathrm{~PB}$ & $3 \mathrm{~PB}$ & $2 \mathrm{~PB}$ & $1 \mathrm{~PB}$ & Phenol \\
\hline \multirow{2}{*}{\multicolumn{6}{|c|}{$\begin{array}{l}\text { Air Sealed } \\
\text { Sample A }\end{array}$}} \\
\hline & & & & & \\
\hline 0 & 220 & 1324 & 814 & 200 & 190 \\
\hline 7 & 223 & 1353 & 772 & 234 & 209 \\
\hline 28 & 191 & 1364 & 634 & 298 & 258 \\
\hline 47 & 228 & 1396 & 552 & 326 & 286 \\
\hline 118.5 & 190 & 1336 & 268 & 356 & 463 \\
\hline 198 & 183 & 1358 & 104 & 272 & 531 \\
\hline 342.5 & 148 & 1291 & 19 & 98 & 687 \\
\hline 492 & 113 & 1306 & 13 & 38 & 808 \\
\hline \multicolumn{6}{|l|}{ Sample B } \\
\hline 0 & 204 & 1317 & 809 & 199 & 188 \\
\hline 7 & 256 & 1383 & 794 & 237 & 212 \\
\hline 28 & 199 & 1372 & 641 & 300 & 256 \\
\hline 47 & 240 & 1352 & 549 & 331 & 283 \\
\hline 118.5 & 214 & 1400 & 270 & 360 & 421 \\
\hline 198 & 173 & 1338 & 130 & 287 & 502 \\
\hline 342.5 & 166 & 1273 & 22 & 119 & 640 \\
\hline 492 & 134 & 1257 & 11 & 43 & 763 \\
\hline \multicolumn{6}{|l|}{ Flowing Air } \\
\hline \multicolumn{6}{|l|}{ Sample C } \\
\hline 0 & 229 & 1312 & 802 & 206 & 186 \\
\hline 7 & 223 & 1359 & 767 & 240 & 228 \\
\hline 28 & 222 & 1398 & 626 & 298 & 323 \\
\hline 47 & 223 & 1360 & 528 & 337 & 401 \\
\hline 118.5 & 228 & 1423 & 256 & 385 & 683 \\
\hline 198 & 241 & 1435 & 93 & 333 & 893 \\
\hline 342.5 & 212 & 1350 & 34 & 213 & 876 \\
\hline 492 & 204 & 1338 & 12 & 102 & 1219 \\
\hline \multicolumn{6}{|l|}{ Sample D } \\
\hline 0 & 232 & 1332 & 819 & 211 & 188 \\
\hline 7 & 227 & 1371 & 789 & 238 & 202 \\
\hline 28 & 237 & 1428 & 662 & 307 & 322 \\
\hline 47 & 261 & 1401 & 539 & 335 & 395 \\
\hline 118.5 & 256 & 1416 & 266 & 381 & 670 \\
\hline 198 & 221 & 1368 & 95 & 340 & 876 \\
\hline 342.5 & 229 & 1347 & 35 & 220 & 1017 \\
\hline 492 & 227 & 1324 & 16 & 109 & 1155 \\
\hline
\end{tabular}


Researchers regressed the data using the Microsoft $\mathrm{f}^{\oplus}$ Excel regression function and obtained the calculated pseudo-first order rate constants for each of the phenylborate species. Table 6 contains these values. Figure 1 shows the behavior of sodium tetraphenylborate in these air sealed and flowing air tests. Sodium tetraphenylborate in the air sealed tests appears to slowly react over the extended $\sim 500$ hour test; whereas the sodium tetraphenylborate in the flowing air test does not appreciably decompose. One explanation is the air is consumed by the lower phenylborates in the air sealed test, converting the solution to an anoxic condition. This anoxic condition supports transition metals, e.g., $\mathrm{Cu}$, in reduced oxidation states capable of reacting with the sodium tetraphenylborate. This atmospheric dependence has been observed previously by Hyder $^{6}$ for triphenylborane, diphenylborinic acid and phenylboronic acid. The calculated pseudo-first order rate constant for the sodium tetraphenylborate decomposition in this anoxic condition $\left(0.0011-0.0013 \mathrm{~h}^{-1}\right)$ is comparable to the data from tests with real waste material from Tank $48 \mathrm{H}^{2}$

Table 5. Elemental Composition (mg/L) of ECC-Containing Filtrate

\begin{tabular}{|c|c|c|c|c|c|c|c|}
\hline \multicolumn{8}{|c|}{$I C P-E S$} \\
\hline $\mathrm{Ag}$ & 4.83 & & B & 192.44 & & $\mathrm{Ca}$ & 0.07 \\
\hline $\mathrm{Cd}$ & 0.95 & & $\mathrm{Cu}$ & 3.84 & & $\mathrm{Cr}$ & 2.59 \\
\hline $\mathrm{Fe}$ & 2.07 & & $\mathrm{Mn}$ & 1.27 & & Mo & 14.72 \\
\hline $\mathrm{Ni}$ & 2.55 & & $\mathrm{~Pb}$ & 19.64 & & $\mathrm{Zn}$ & 10.55 \\
\hline \multicolumn{8}{|c|}{$I C P-M S$} \\
\hline & $\mathrm{Pd}$ & 0.05 & & & $\mathrm{Rh}$ & 1.06 & \\
\hline & $\mathrm{Ru}$ & 1.95 & & & $\mathrm{Cu}$ & 1.32 & \\
\hline
\end{tabular}

Table 6. Pseudo-First Order Rate Constants $\left(\mathrm{h}^{-1}\right)$ of Filtered Slurry

\begin{tabular}{clllll}
\hline Component & \multicolumn{1}{c}{ Air Sealed } & & \multicolumn{3}{l}{ Flowing Air } \\
Sample No. & A & B & C & D \\
4PB & 0.0013 & 0.0011 & $0.00013^{\mathrm{NR}}$ & $0.00011^{\mathrm{NR}}$ \\
3PB & $0.00013^{\mathrm{NR}}$ & $0.00015^{\mathrm{NR}}$ & $\mathrm{NR}$ & $\mathrm{NR}$ \\
2PB & 0.009 & 0.009 & 0.0092 & 0.009 \\
1PB & 0.0053 & 0.005 & 0.0045 & 0.0048 \\
\hline
\end{tabular}

NR $=$ No Statistically Significant Reaction 
4PB Decomposition

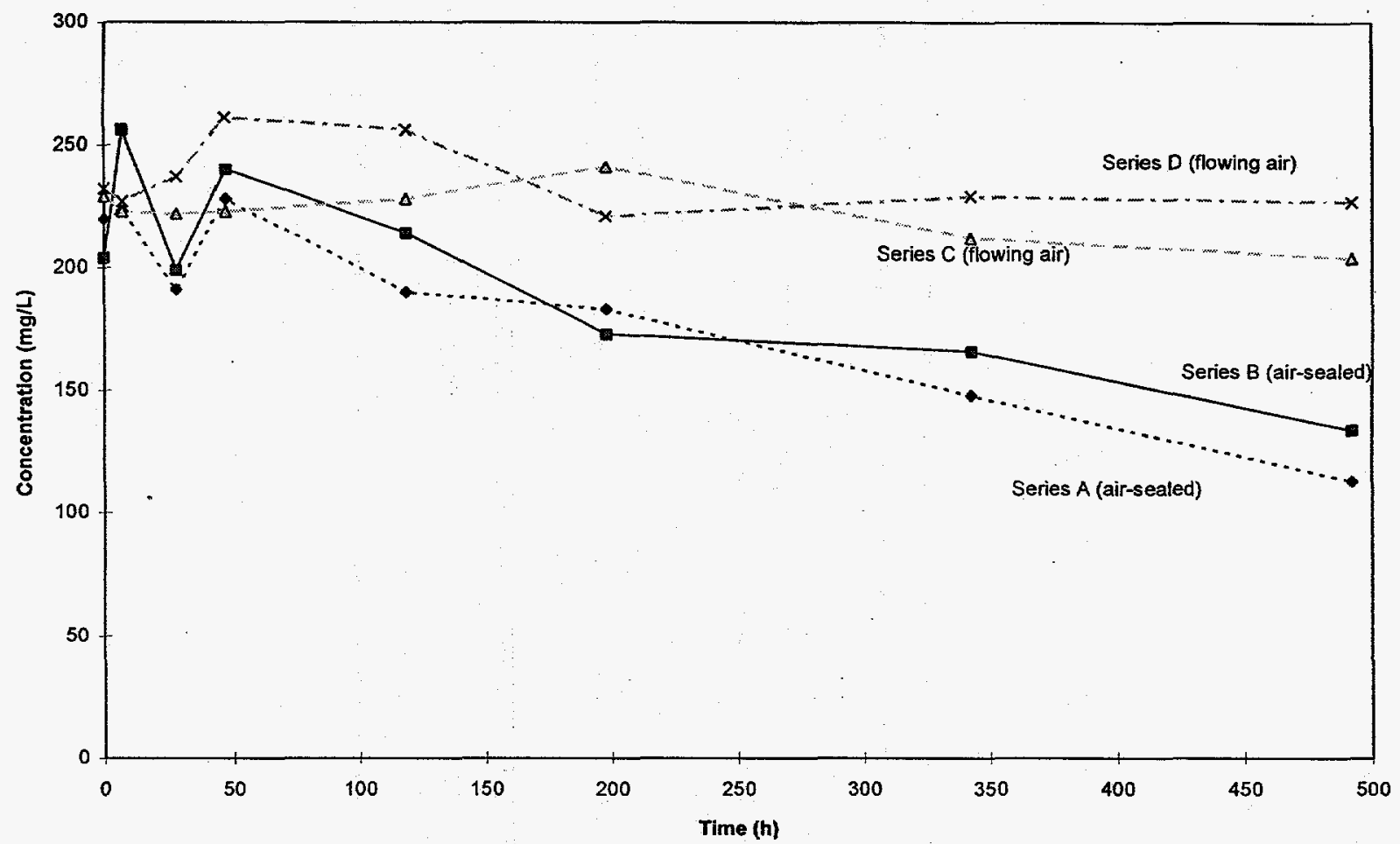

Figure 1. Sodium Tetraphenylborate Decomposition in ECC-Containing Filtrate

Figure 2 shows the behavior of triphenylborane in the ECC-containing filtrate. The triphenylborane remains relatively stable under these conditions. Attempts to regress the decomposition data did not reveal statistically significant rate constants. However, in both the flowing air and sealed experiments, the diphenylborinic acid and phenylboronic acid decompose readily as shown in Figure 3. The calculated pseudo-first order rate constants measured $0.009 \mathrm{~h}^{-1}$ and $0.005 \mathrm{~h}^{-1}$ for diphenylborinic acid and phenylboronic acid, respectively. The rate constants appear relatively independent of the oxygen content of the filtrate, exhibiting the same behavior in both systems. Phenylboronic acid showed the most dependence on atmosphere, but the dependence was not statistically significant. These rate constants are significant with a half life at $45^{\circ} \mathrm{C}$ of approximately 100 hours. 
3PB Decomposition

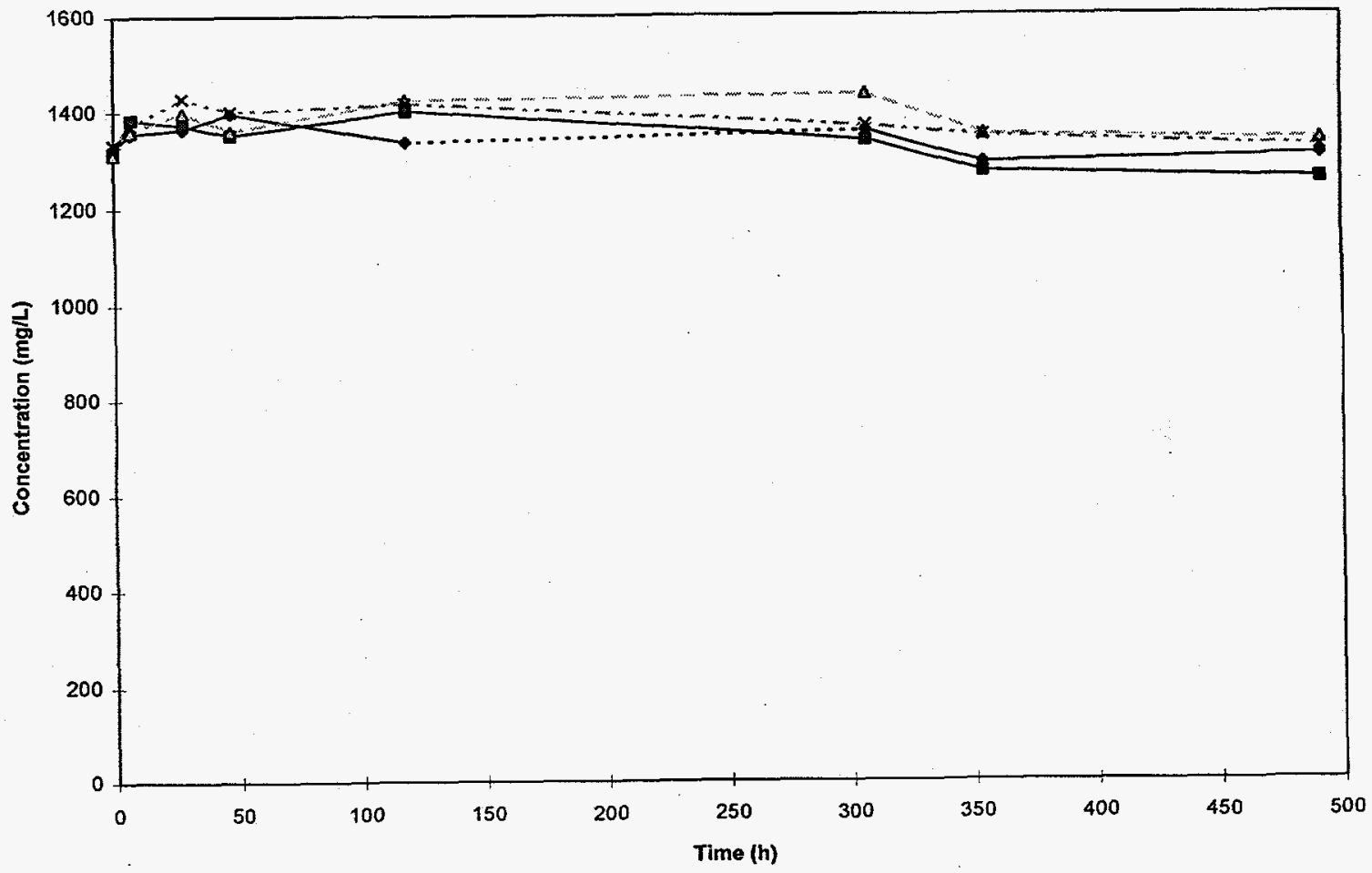

Figure 2. Triphenylborane Decomposition in ECC-Containing Filtrate

2PB and IPB Decomposition in Filtrate

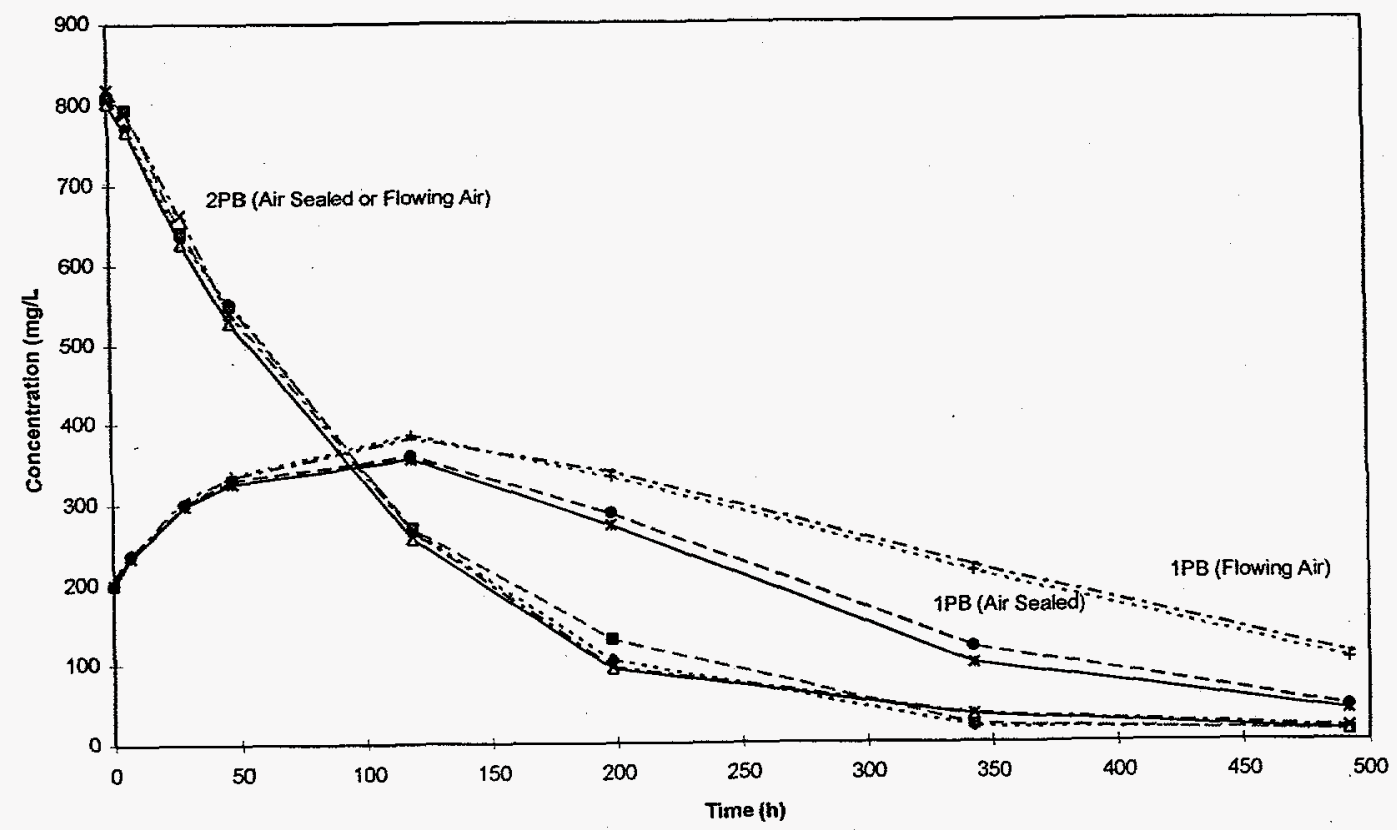

Figure 3. Diphenylborinic Acid and Phenylboronic Acid Decomposition in ECC-Containing Filtrate 
Researchers placed additional copper catalyst in the ECC-containing filtrate under flowing air and sealed air conditions to determine the effect of copper concentration. Simultaneously, palladium was spiked into two other reactions vessels containing the filtrate raising the reactive catalyst concentration to nominally $10 \mathrm{mg} / \mathrm{L}$. In the case of the palladium experiments, two separate additions were performed. The first palladium addition raised the concentration from $0.05 \mathrm{mg} / \mathrm{L}$ to $1.3 \mathrm{mg} / \mathrm{L}$ while the second addition raised the level to $10 \mathrm{mg} / \mathrm{L}$. Visual observations revealed no evidence of precipitation of the catalyst.

Table 7 provides the concentrations of the phenylborate species and phenol observed in the catalyst addition experiments. In the case of increased copper catalyst, sodium tetraphenylborate appears relatively stable under both flowing air and sealed air conditions. Under flowing air conditions and increased copper concentration, sodium tetraphenylborate appears to react slightly faster than in the initial filtrate, very similar to the decomposition to the air sealed system. Triphenylborane decomposes faster in the air sealed system. Diphenylborinic acid and phenylboronic acid both react rapidly. Phenol production is favored in the flowing air system as expected. Figures 4 and 5 show the behavior of the phenylborate species in the air sealed and flowing air systems, respectively.

Researchers regressed the concentration data and have calculated pseudo first order rate constants for each of the phenylborate species. Table 8 lists these rate constants. The rate constant for sodium tetraphenylborate does not appear to show a dependency on the copper concentration, except in the flowing air system. However, the rate constants calculated for diphenylborinic acid and phenylboronic acid increased by a factor of 5 with the increased copper concentration indicating a first order dependency. 
Table 7. Copper and Palladium Catalysis of Phenylborate Decomposition

\begin{tabular}{llllll} 
Elapsed Time (h) & $4 \mathrm{~PB}$ & $3 \mathrm{~PB}$ & $2 \mathrm{~PB}$ & $1 \mathrm{~PB}$ & Phenol \\
Copper sealed in Air & & & & & \\
0 & 237 & 1415 & 410 & 359 & 508 \\
23 & 223 & 1380 & 198 & 324 & 588 \\
55.5 & 236 & 1273 & 69 & 179 & 626 \\
72 & 191 & 1177 & 38 & 107 & 650 \\
95 & 203 & 1185 & 23 & 59 & 878 \\
167.5 & 181 & 1109 & 11 & 10 & 813 \\
336 & 154 & 1003 & 10 & 10 & 918 \\
527 & 103 & 859 & 10 & 10 & 964 \\
Copper under Flowing Air & & & & & \\
0 & 242 & 1375 & 293 & 363 & 570 \\
23 & 219 & 1303 & 128 & 285 & 1141 \\
55.5 & 244 & 1368 & 37 & 157 & 1076 \\
72 & 239 & 1355 & 24 & 111 & 1096 \\
98.5 & 211 & 1309 & 13 & 50 & 1248 \\
167.5 & 217 & 1316 & 14 & 10 & 1318 \\
336 & 198 & 1216 & 10 & 10 & 1345 \\
527 & 191 & 1147 & 10 & 10 & 1403 \\
Palladium Sealed in Air & & & & & \\
0 & 251 & 1413 & 424 & 432 & 484 \\
23 & 224 & 1388 & 330 & 373 & 568 \\
55.5 & 227 & 1333 & 225 & 350 & 600 \\
$72 *$ & 232 & 1354 & 190 & 334 & 616 \\
95.75 & 190 & 1201 & 154 & 280 & 694 \\
167.5 & 176 & 1103 & 97 & 13 & 766 \\
336 & 131 & 967 & 37 & 44 & 888 \\
527 & 81 & 812 & 33 & 10 & 1015 \\
Palladium in Flowing Air & & & & & \\
0 & 260 & 1413 & 426 & 363 & 517 \\
23 & 213 & 1363 & 311 & 379 & 580 \\
55.5 & 227 & 1290 & 197 & 348 & 630 \\
$72 *$ & 242 & 1347 & 157 & 340 & 710 \\
95.25 & 210 & 1301 & 115 & 279 & 824 \\
167.5 & 209 & 1234 & 63 & 41 & 943 \\
336 & 204 & 1151 & 40 & 55 & 1078 \\
527 & 200 & 1078 & 39 & 38 & 1159 \\
& & & & & \\
\hline Secos & & & \\
0 & & &
\end{tabular}

*Second palladium addition made following the 72 hour sample. 
Table 8. Pseudo-First Order Rate Constants $\left(\mathrm{h}^{-1}\right)$ of Catalyst Additions

\begin{tabular}{|c|c|c|c|c|}
\hline \multirow[t]{2}{*}{ Component } & \multicolumn{2}{|c|}{ Copper } & \multicolumn{2}{|c|}{ Palladium* } \\
\hline & Air Sealed & Flowing Air & Air Sealed & Flowing Air \\
\hline $4 \mathrm{~PB}$ & 0.0017 & 0.0012 & $\begin{array}{l}0.0014 \\
(0.0017)\end{array}$ & $\begin{array}{l}0.0018 \\
(0.0002)\end{array}$ \\
\hline $3 \mathrm{~PB}$ & 0.0012 & 0.0004 & $\begin{array}{l}0.0009 \\
(0.0011)\end{array}$ & $\begin{array}{l}0.0013 \\
(0.0005)\end{array}$ \\
\hline $2 \mathrm{~PB}$ & 0.045 & 0.042 & $\begin{array}{l}0.014 \\
(0.017)\end{array}$ & $\begin{array}{l}0.018 \\
(0.012)\end{array}$ \\
\hline $1 \mathrm{~PB}$ & 0.031 & 0.027 & $\begin{array}{l}0.0113 \\
(0.058)\end{array}$ & $\begin{array}{l}0.010 \\
(0.030)\end{array}$ \\
\hline
\end{tabular}

*Values in () are for $10 \mathrm{mg} / \mathrm{L} \mathrm{Pd}$; others are for $1.3 \mathrm{mg} / \mathrm{L}$

Note: $\mathrm{Cu}$ and $\mathrm{Pd}$ additions were to a filtrate containing $1-3 \mathrm{mg} / \mathrm{L} \mathrm{Cu}$ and $0.05 \mathrm{mg} / \mathrm{L} \mathrm{Pd}$

In the case of the palladium additions, sodium tetraphenylborate does not appear to exhibit a palladium concentration dependency showing a rate constant on the order of 0.001 to $0.002 \mathrm{~h}^{-1}$. The reactivity of triphenylborane with the increased palladium concentrations also resemble the reactivity in the copper catalyzed system. Figures 6 and 7 show the behavior of the palladium catalyzed systems. For diphenylborinic acid, the rate constants are increased slightly with increased palladium concentration but remain lower than the rate constants calculated for the copper system. Copper seems the dominant catalyst for the decomposition of diphenylborinic acid. The behavior of phenylboronic acid indicates a slightly faster reaction in the palladium system than the copper system. The calculated rate constant for the decomposition of $1 \mathrm{~PB}$ nearly doubles $\left(0.03\right.$ to $\left.0.058 \mathrm{~h}^{-1}\right)$ in the air-sealed experiments. However, in the Flowing Air experiments, the rate constants are similar. 
Page 15 of 21

Cu-Catalysis Air Sealed

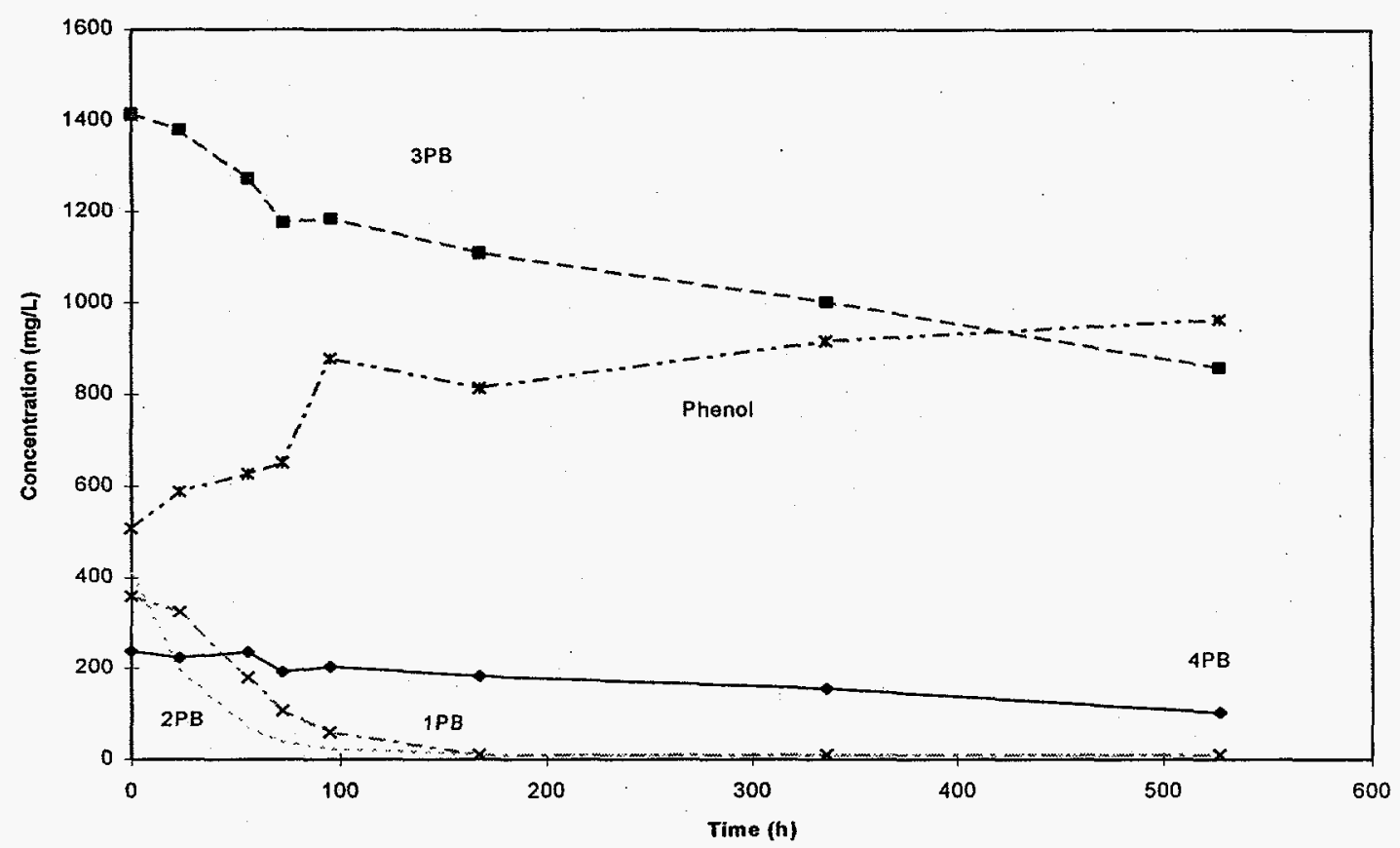

Figure 4. Copper Catalysis of an Air Sealed System.

Cu Catalys is - Flowing A ir

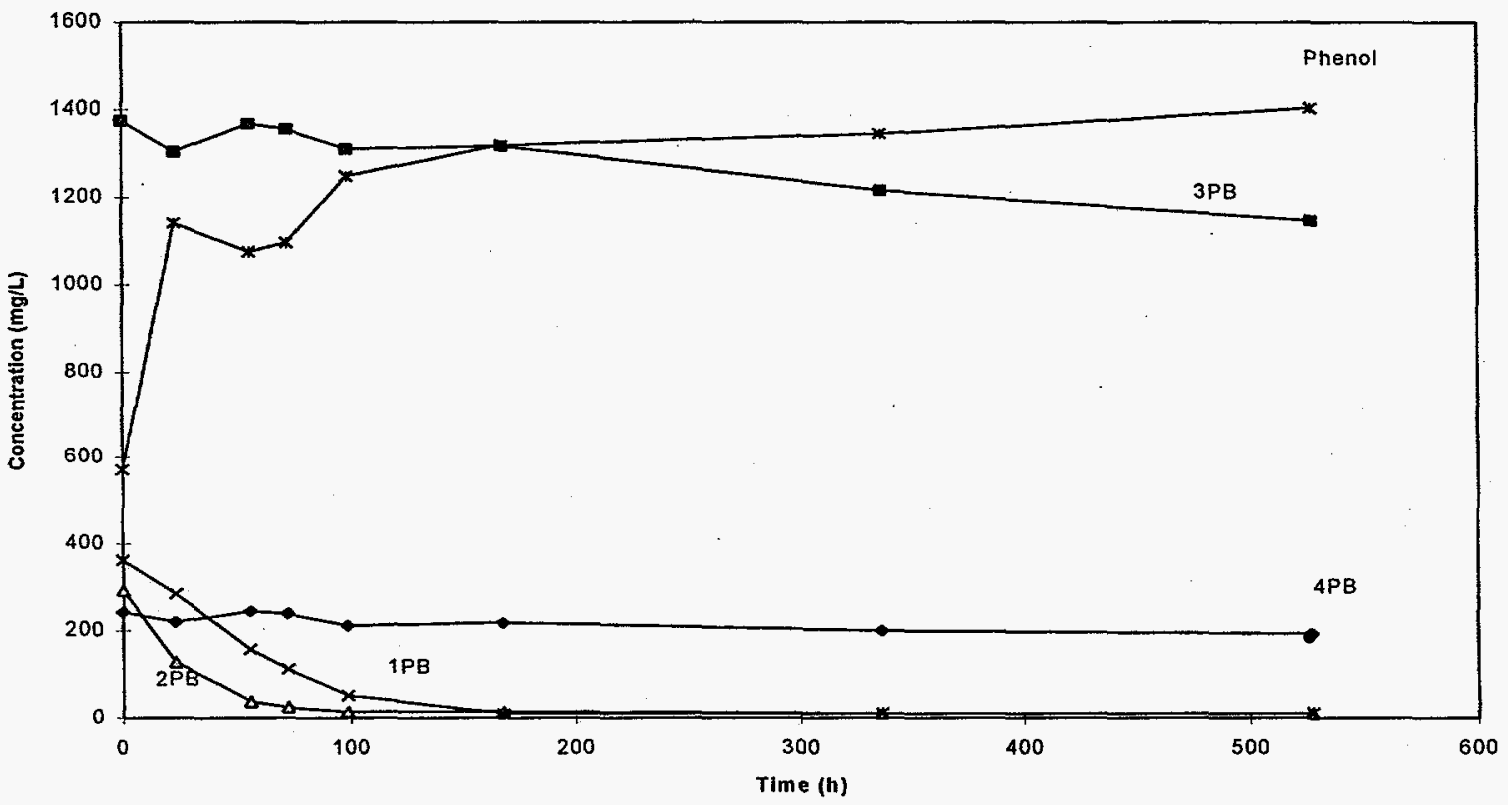

Figure 5. Copper Catalysis in a Flowing Air System. 


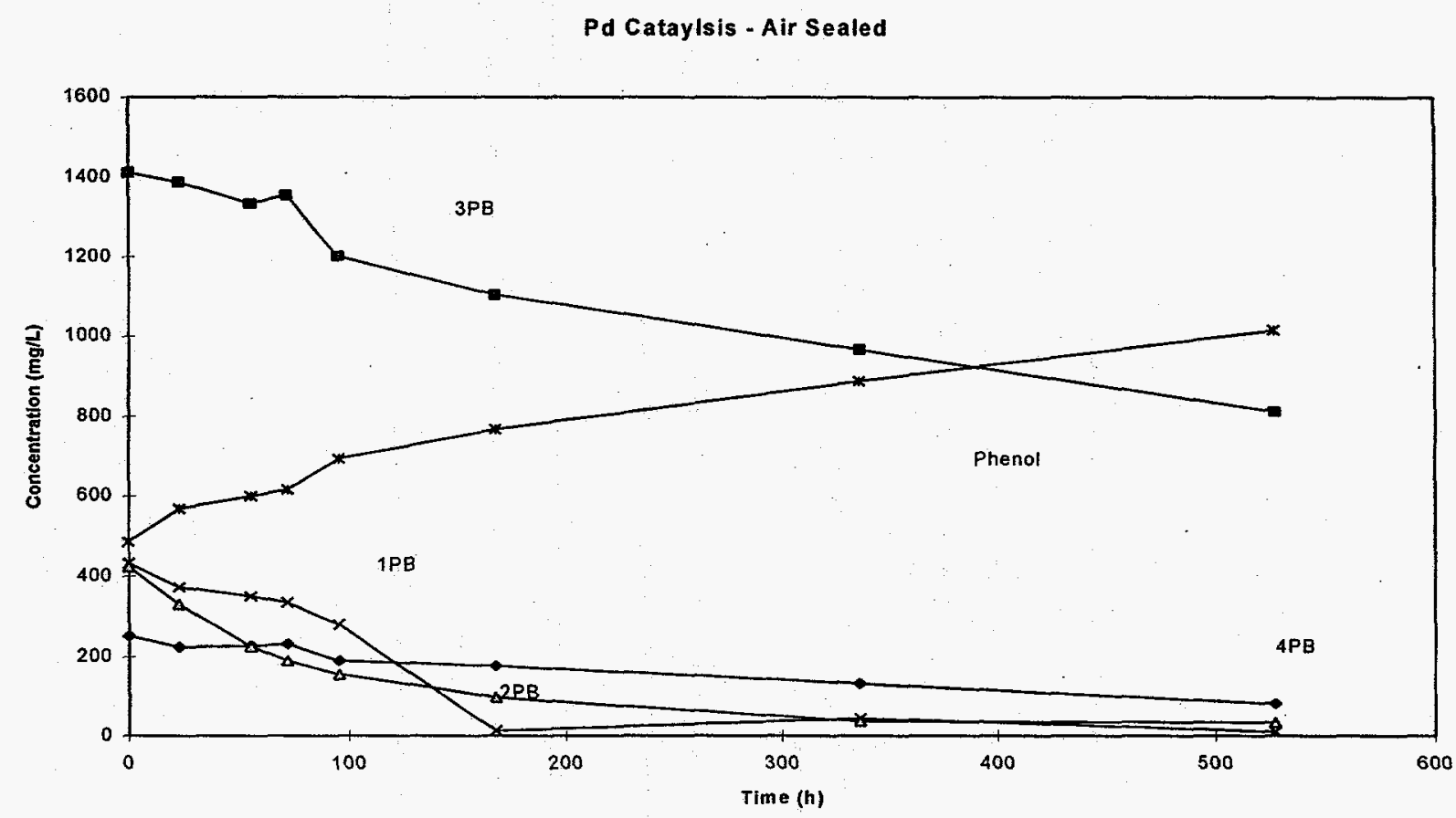

Figure 6. Palladium Catalysis in a Flowing Air System.

Pd Catalysis - Flowing Air

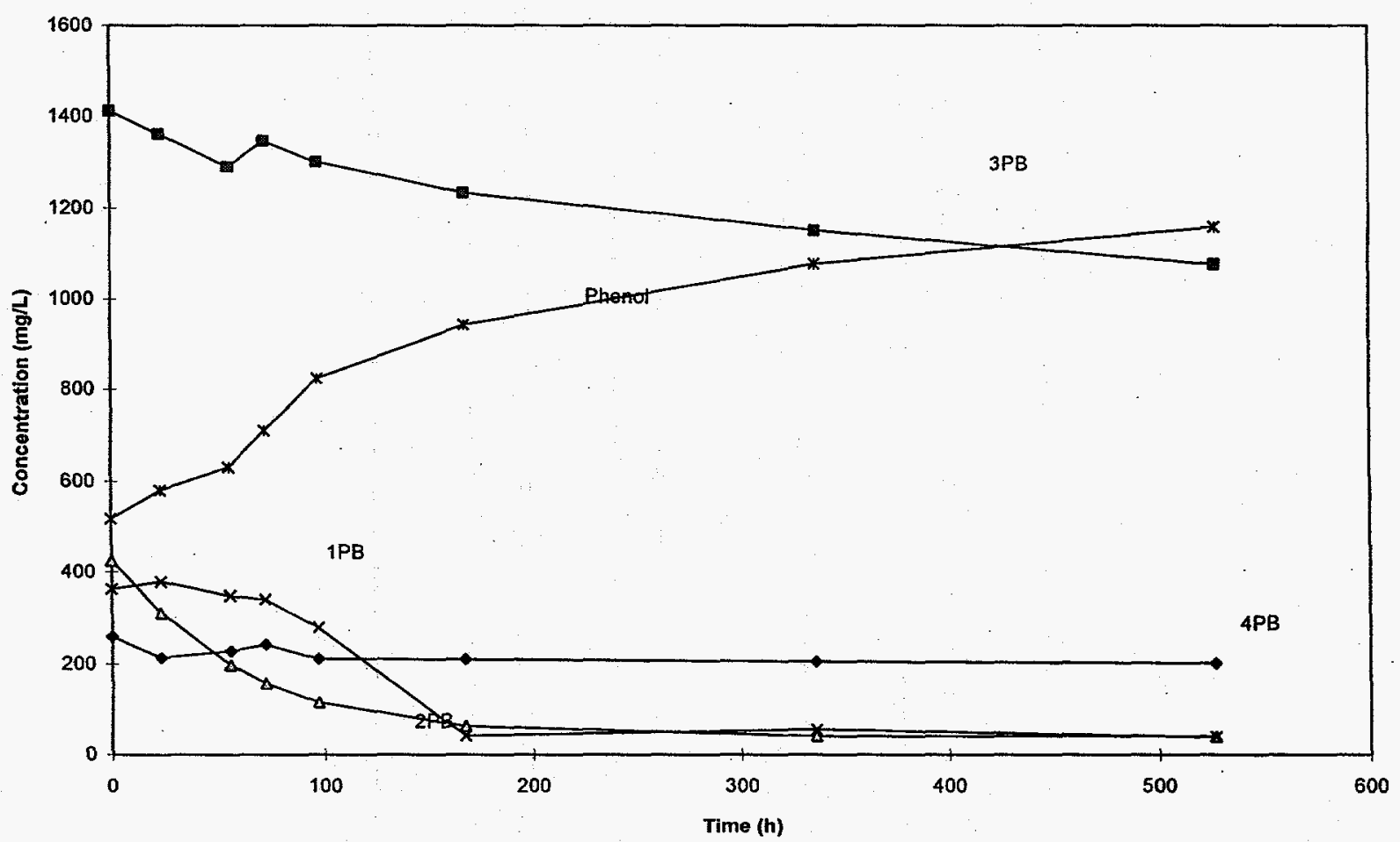

Figure 7. Palladium Catalysis in an Air Sealed System. 


\section{Comparisons of Rate Constant for Phenylborate Species}

Table 9 contains the pseudo-first order rate constants calculated from data measured by several different researchers investigating decomposition of phenylborate species in aqueous alkaline media. Most of the data is for the lower phenylborate species (2PB and 1PB). The data is for temperatures near $45^{\circ} \mathrm{C}$. It must be recognized that these data derived from different experimental conditions but trends can be observed by examination of the relative values.

Table 9. Comparison of Rate Constants $\left(\mathrm{h}^{-1}\right)$ for Filtrates near $45^{\circ} \mathrm{C}$

\begin{tabular}{|c|c|c|c|c|c|}
\hline & This Study & & $\begin{array}{l}\text { Crawford } \\
\text { Peterson }^{\mathrm{a}}\end{array}$ & $\underline{\text { Hyder }}^{b}$ & Barnes \\
\hline $4 \mathrm{~PB}$ & $\begin{array}{l}\text { Sealed } \\
0.0013(\mathrm{f}) \\
0.0017(\mathrm{Cu}) \\
0.0017(\mathrm{Pd})\end{array}$ & $\begin{array}{l}\text { Flowing } \\
0.0001(\mathrm{f}) \\
0.0012(\mathrm{Cu}) \\
0.0002(\mathrm{Pd})\end{array}$ & & & $\begin{array}{l}0.00027^{\mathrm{c}} \\
0.0007^{\mathrm{d}} \\
0.0003^{\mathrm{e}}\end{array}$ \\
\hline $3 \mathrm{~PB}$ & $\begin{array}{l}0.00014(\mathrm{f}) \\
0.012(\mathrm{Cu}) \\
0.0011(\mathrm{Pd})\end{array}$ & $\begin{array}{l}\text { No Reaction } \\
0.004(\mathrm{Cu}) \\
0.0005(\mathrm{Pd})\end{array}$ & $\begin{array}{l}0.0007(1.3 \mathrm{mg} / \mathrm{L}) \\
0.0010(3.2 \mathrm{mg} / \mathrm{L}) \\
0.0016(10 \mathrm{mg} / \mathrm{L})\end{array}$ & $\begin{array}{l}0.003 \text { (Air) } \\
0.013\left(\mathrm{~N}_{2}\right)\end{array}$ & $\begin{array}{l}\text { Wilmarth } \\
\text { Crawford } \\
\text { Peterson }\end{array}$ \\
\hline $2 \mathrm{~PB}$ & $\begin{array}{l}0.009(\mathrm{f}) \\
0.045(\mathrm{Cu}) \\
0.017(\mathrm{Pd})\end{array}$ & $\begin{array}{l}0.0091(\mathrm{f}) \\
0.042(\mathrm{Cu}) \\
0.012(\mathrm{Pd})\end{array}$ & $\begin{array}{l}0.0202(1.3 \mathrm{mg} / \mathrm{L}) \\
0.0317(3.2 \mathrm{mg} / \mathrm{L}) \\
0.0561(10 \mathrm{mg} / \mathrm{L})\end{array}$ & $\begin{array}{l}0.12 \text { (Air) } \\
0.03 \text { (N2) }\end{array}$ & 0.026 (Air) \\
\hline $1 \mathrm{~PB}$ & $\begin{array}{l}0.0053(\mathrm{f}) \\
0.031(\mathrm{Cu}) \\
0.058(\mathrm{Pd})\end{array}$ & $\begin{array}{l}0.005(\mathrm{f}) \\
0.027(\mathrm{Cu}) \\
0.030(\mathrm{Pd})\end{array}$ & $\begin{array}{l}0.0008(1.3 \mathrm{mg} / \mathrm{L}) \\
0.0018(3.2 \mathrm{mg} / \mathrm{L}) \\
0.0049(10 \mathrm{mg} / \mathrm{L})\end{array}$ & $\begin{array}{l}0.125 \text { (Air) } \\
0.012 \text { (N2) }\end{array}$ & 0.039 (Air) \\
\hline
\end{tabular}

(f) = filtrate

${ }^{\mathrm{a} C}$ Crawford and Peterson, WSRC-TR-97-0045 [Cu-only, Air Sealed, temperature corrected to $45^{\circ} \mathrm{C}$ ]

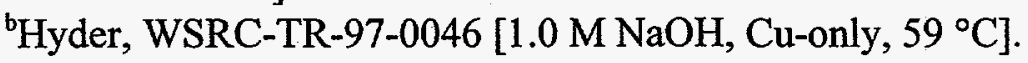

${ }^{\mathrm{c}}$ Calculated from Barnes, WSRC-TR-97-0060, Test $7\left[2.7 \mathrm{M} \mathrm{Na}+55^{\circ} \mathrm{C}\right.$, Comprehensive Catalyst]

${ }^{\mathrm{d}}$ Calculated from Barnes, WSRC-TR-96-0351, Test 5A [0.1 M NaOH, $\left.1.69 \mathrm{mg} / \mathrm{L} \mathrm{Cu}, 40^{\circ} \mathrm{C}\right]$ (Note 3 other tests showed no reaction)

${ }^{e}$ Same as (d) but $50^{\circ} \mathrm{C}$, Tests $9 \mathrm{~A}$ and $10 \mathrm{~A}$ with $1.2 \mathrm{mg} / \mathrm{L} \mathrm{Cu}$.

fWilmarth, et al., WSRC-TR-97-0238, $40^{\circ} \mathrm{C}, 1 \mathrm{M} \mathrm{NaOH}$. 
Barnes ${ }^{14,15}$ studied the decomposition of sodium tetraphenylborate using either copper ion or a comprehensive catalyst mixture at temperatures between $40^{\circ} \mathrm{C}$ and $55^{\circ} \mathrm{C}$. The pseudo-first order rate constants varied from $0.00027 \mathrm{~h}^{-1}$ to $0.0007 \mathrm{~h}^{-1}$. These rate constants are similar to those calculated from the flowing air-filtrate test described in this report. However, the rate constant reported for the sealed air system $(0.0013 \mathrm{~h}-1)$ is nominally an order of magnitude larger. Addition of copper or palladium do not significantly raise the flowing air rate of decomposition, as previously mentioned. However, addition of copper to $10 \mathrm{mg} / \mathrm{L}$ concentration, increases the rate constant in the flowing air system.

In the case of triphenylborane, the simulated Tank $50 \mathrm{H}$ filtrate is non-reactive. Additions of copper or palladium increase the rate constant. These values of the rate constants are approximately the same as Crawford and Peterson ${ }^{5}$ measured but are significantly less than the values reported by Hyder. ${ }^{6}$ The data reported herein is in agreement with Hyder that triphenylborane reacts faster in the presence of copper when oxygen is limited.

Several different studies have been performed on the decomposition of diphenylborinic acid. The pseudo-first order rate constant derived from the filtrate is lower than the results of the other experimenters. Addition of copper to the $10 \mathrm{mg} / \mathrm{L}$ level raised the reactivity to that observed by Crawford and Peterson, ${ }^{5}$ Hyder, ${ }^{6}$ and Wilmarth, Crawford and Peterson. ${ }^{\mathrm{b}}$ The rate constant calculated from the experimental data when copper is added agrees well from each researcher with a value close to 0.03 to $0.04 \mathrm{~h}^{-1}$ at $45^{\circ} \mathrm{C}$.

The data on phenylboronic acid appear to agree when using the reaction vessel designed by Hyder, ${ }^{6}$ but does not agree with the filtrate experiments of Crawford and Peterson. ${ }^{5}$ The rate constant reported by Crawford and Peterson is about an order of magnitude lower than the copper addition. The value is, however, similar to the value for the current filtrate test. As previously mention, the largest rate constant is that found in the palladium addition experiment.

\section{Conclusions}

Researchers studied the decomposition of the phenylborates in systems containing filtrate from a reacting slurry containing the Enhanced Comprehensive Catalyst. Phenylborate decomposition in both air sealed and flowing air systems have been examined. These studies were performed to determine the behavior expected for Tank $50 \mathrm{H}$. Sodium tetraphenylborate and triphenylborane remain relatively stable in these conditions exhibiting reactivity similar to copper catalysis.

Diphenylborinic acid and phenylboronic acid, however, react quickly with the catalyst concentrations which passed the filter. These experiments show pseudo-first order rate constants on the order of $0.005-0.009 \mathrm{~h}^{-1}$ have been calculated from the experimental data. 


\section{References}

1. A. L. Watkins, "DNFSB Recommendation 96-1 Implementation Plan," DOE-SR Memorandum to S. P. Cowan, October 21, 1996.

2. D. D. Walker, M. J. Barnes, C. L. Crawford, R. F. Swingle, R. A. Peterson, M. S. Hay, and S. D. Fink, "Decomposition of Tetraphenylborate in Tank 48H (U)," WSRC-TR-96-0113, rev 0, May 10, 1997.

3. D. D. Walker, M. L. Hyder, M. J. Barnes, and R. A. Peterson, "Intermediate Decomposition rates," SRP-IWP-97-0021, February 26, 1997.

4. W. R. Wilmarth, "Solubility of Tetraphenylborate Intermediates," WSRC-RP-97-0094, April 4, 1997.

5. C. L. Crawford and R. A. Peterson, "Decomposition Studies of Triphenylboron, Diphenylborinic Acid, and Phenylboric Acid in Aqueous Alkaline Solutions Containing Copper,"WSRC-TR-97-0045, Rev. 0, February 11, 1997.

6. M. L. Hyder, "The Role of Oxygen in the Copper-Catalyzed Decomposition of Phenyl Borates in Aqueous Solutions, "WSRC-TR-97-0046, March 17, 1997.

7. C. L. Crawford and R. A. Peterson, " Decomposition Studies of Triphenylborane, Diphenylborinic Acid, and Phenylboronic Acid in Aqueous Alkaline Solutions containing Potential Catalysts (U),"WSRC-TR-97-0225, Rev. 0, July 22, 1997.

8. J. E. Marra and J. T. Carter, "Soluble TPB Decomposition and Catalysis," HLE-TTR-97-008, Rev. 0, November 14, 1996.

9. C. L. Crawford, "Decomposition Studies of Tetraphenylborate Slurries," WSRC-TR-970046, Rev. 0, May 6, 1997.

10. "High Performance Liquid Chromatograph Operating Procedure," Manual L16.1, Procedure ADS-2655, Rev. 2, November 10, 1996.

11. W. R. Wilmarth and C. L Crawford, "Task Technical Plan for the Additional Decomposition Studies of Triphenylborane, Diphenylborinic Acid, and Phenylboronic Acid in Aqueous Solutions containing the Enhanced Comprehensive Catalyst (U)," WSRC-RP-97-293, June 5, 1997.

12. W. R. Wilmarth and C. L Crawford, "Task Quality Assurance Plan for the Additional Decomposition Studies of Triphenylborane, Diphenylborinic Acid, and Phenylboronic Acid in Aqueous Solutions containing the Enhanced Comprehensive Catalyst (U)," WSRC-RP-97294, June 5, 1997. 
13. M. J. Barnes, "Sodium Tetraphenylborate Catalyst Identification: Phase B and C Statistical Design Studies (U)," WSRC-TR-97-0230, Rev. 0, August 13, 1997.

14. M. J. Barnes and T. B. Edwards, "Copper Catalyzed Sodium Tetraphenylborate Decomposition Kinetic Studies (U)," WSRC-TR-96-0351, Rev. 0, November 7, 1996.

15. M. J. Barnes, C. L. Crawford, and C. A. Nash, "Sodium Tetraphenylborate Catalyst Identification: Preliminary Studies Set 1 (U),"WSRC-TR-97-0060, Rev. 0, March 6, 1997. 


\section{Approvals}

Authors:

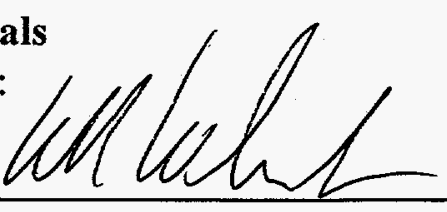

W. R. Wilmarth, Waste Processing Technology

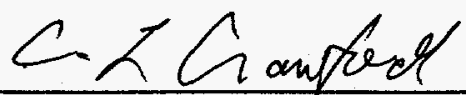

C. L. Crawford, Waste Processing Technology

$$
11-24-97
$$

Date

$$
11-25.97
$$

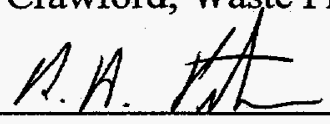 \\ M. H. HA}

R. A. Peterson, Waste Processing Technology
Date

$11 / 25 / 97$

Design Check

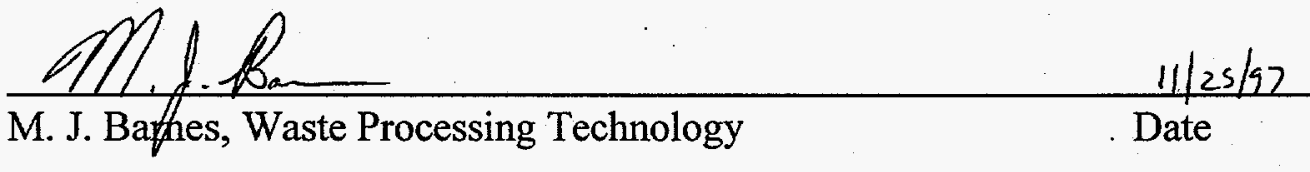

Management

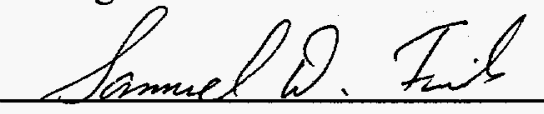

S. D. Fink, Manager, Level 4 Manager,

Waste Processing Technology

\section{Date}

Date

$\begin{array}{lc}\text { Th lant } & 12 / 5 / 97 \\ \text { J. T. Carter, Leader } & \text { Date } \\ \text { In-Tank Precipitation Flow Sheet Team } & \end{array}$

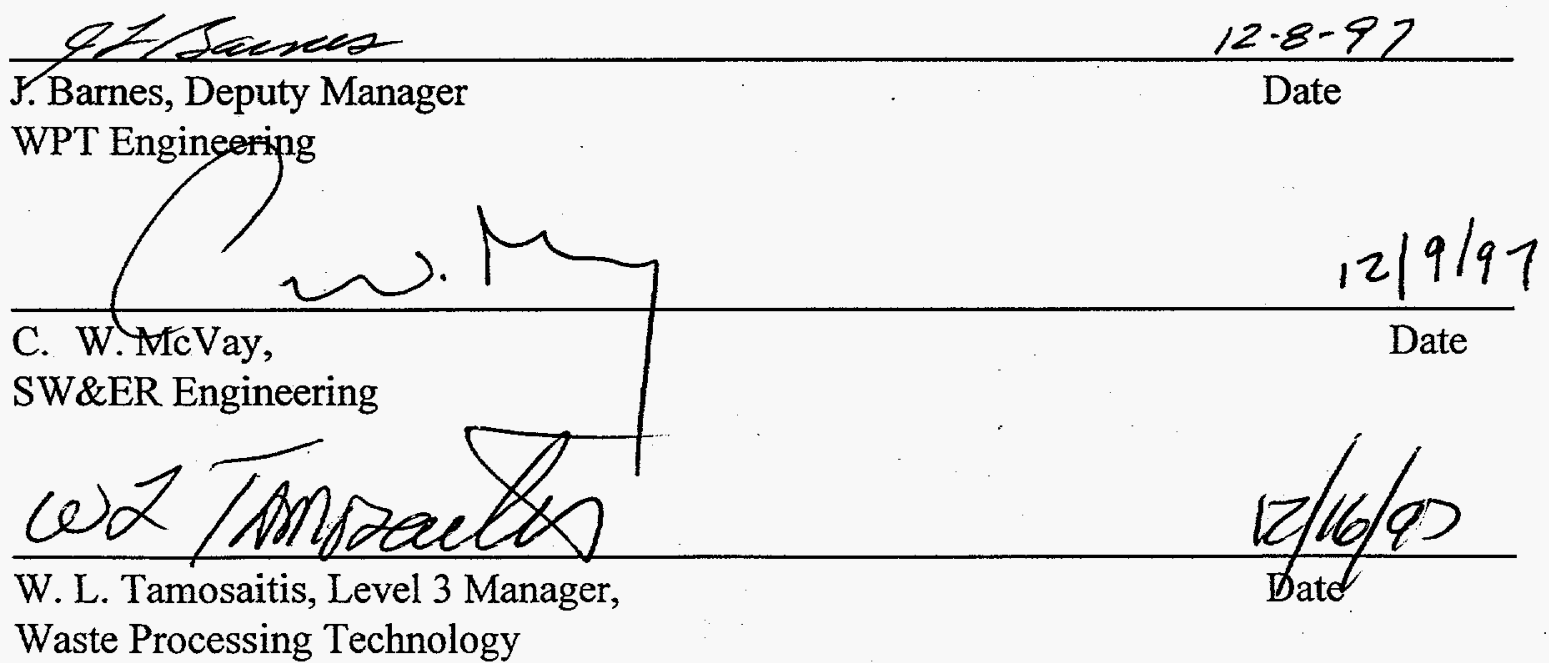


WSRC-TR-97-00383, Rev. 0

\section{DISTRIBUTION}

Barnes, M. J., 773-A

Britt, T. E., 730-2B

Byrd, D., 704-56H

Carter, J. T., 704-25S

Cauthen, G. L., 241-119H

Clark, W. C., 241-119H

Crawford, C. L., 773-43A

Eibling, R., 704-T

Elder, H. H., 704-S

Fink, S. D., 773-A

Fowler, J. R., 241-121H

Griffin, J. C., 773-A

Hitchler, M. J., 730-2B

Holtzscheiter, E. W., 773-A

Hyder, M. L, 773-A

Jacobs, R. A., 704-T

Johnson, M. D., 704-56H

Keefer, M. T., 704-56H

Landon, L. F., 704-T

Lewis, B. L., 703-H

Lex, T. J., 719-4A

Marek, J. C., 704-T
McCabe, D. J., 773-43A

Menna, J. D., 241-119H

Miller, M. S., 704-56H

Montini, M. J., 704-56H

Morin, J. P., 719-4A

Nash, C. A., 773-A

Nelson, L. M., 773-43A

Papouchado, L. M., 773-A

Peterson, R. A., 773-A

Rutland, P. L., 241-152H

Satterfield, R. M., 719-4A

Swingle, R. F., 773-A

Tamosaitis, W. L., 773-A

Taylor, G. A., 703-H

Van Pelt, W. B., 676-1T

Walker, D. D. 773-A .

Wiggins, A. W., 241-152

Wilmarth, W. R., 773-A

Wooten, A. L., 732-B

Wright, G. T., 773-A

TIM, 703-43A

HLWE File Room,File Code 1.2.5.1, 703-H

LWP Files, c/o A. Patterson, 773-A

ITP Files/L. Sumner, 704-56H 